CZASOPISMO INŻYNIERII LACDOWEJ, ŚRODOWISKA I ARCHITEKTURY JOURNAL OF CIVIL ENGINEERING, ENVIRONMENT AND ARCHITECTURE

JCEEA, t. XXXII, z. 62 (3/I/15), lipiec-wrzesień 2015, s. 365-373

\author{
Janusz RAK $\mathbf{R}^{1}$ \\ Katarzyna PIETRUCHA-URBANIK ${ }^{2}$
}

\title{
NEW DIRECTIONS FOR THE PROTECTION AND EVOLUTION OF WATER SUPPLY SYSTEMS - SMART WATER SUPPLY
}

\begin{abstract}
Water supply system should have excellent protection in case of undesirable events occurrence. In the future protection of these systems will be ensured through the use of intelligent management of smart metering and the implementation of the second generation CPTED strategies, presenting a new perspective on critical infrastructure protection, taking into account any possible crime, terrorism, sabotage or disaster. The paper presents the problem of the effective protection of critical infrastructure and the attention was drawn to appropriate protection of critical components from attacks, disasters and other adverse events. On this background the protection principles for water supply systems were formulated, the purpose of which is to prepare the resources and the public for undesirable events causing a threat to both human health and infrastructure. In case of the possibility of managing the shut off of particular recipients, not only areas, the priority of importance of providing water should be established. The exclusion of households seems to be a solution with the smallest financial losses. However, the attention should be paid to the so-called sensitive customers, e.g. the disabled people, the elderly, families with small children, etc. For proper operation of municipal infrastructure specialized companies are responsible which, in addition to managing the systems, are also responsible for ensuring protection of sensitive elements connected or used by them. The most obvious example of urban critical infrastructure system is the collective water supply system.
\end{abstract}

Keywords: protection, smart grid, water supply decentralization, smart water supply

\section{Introduction}

In ancient times, there were centralized water supply systems. During the dark medieval times they were completely forgotten. Until the nineteenth cen-

${ }^{1}$ Janusz Rak, Politechnika Rzeszowska, al. Powstańców Warszawy 12, 35-959 Rzeszów, tel. 17 8651449, rakjan@prz.edu.pl

2 Autor do korespondencji/corresponding author: Katarzyna Pietrucha-Urbanik, Politechnika Rzeszowska, al. Powstańców Warszawy 12, 35-959 Rzeszów, tel. 17 8651703, kpiet@prz.edu.pl 
tury, there were almost only dispersed sources of water supply that were independent of each other and supplied the separated local recipients. Since the midnineteenth century, the re-development trend of large water systems, serving many customers over large areas, has been seen. It was supported by a decline in unit cost of water production in such systems. The other problem is the water network age, as the major project of constructing municipal water supply was performed in the thirties of the twentieth century, what means that such network qualifies for renewal or replacement. The strategy for water pipes renewal should be taken at the level of two percent per year and the water pipes amortization period ranges from 50 to 125 years. It constitutes a significant problem assuming that water supply network constitutes up eighty percent of the water supply company property value.

The turn of the nineteenth and twentieth century along with the mastery of the water distribution technologies allowed for the location of water production plants close to abundant water sources. Local scattered sources were only the emergency supply in case of water supply interruptions or supplied small autonomous recipients, who were not connected to central water supply systems. The share of independent water producers had fallen to about 20-30\% [7, 8]. Market was dominated by water companies, which were water producers and water suppliers [5]. Problems of using monopolistic position and significant risk of failures occurred. This, in turn, triggers the processes for de-monopolization and privatization of the water sector by allowing the construction of water supply tanks near the end users, utilizing local water resources [9]. It is connected with the need to improve water safety by improving delivery certainty and reducing network losses [6]. The development of independent technology and equipment for water treatment contributed to such situation. More and more often the concept of developing group water supply systems faces investment barriers related to lack of permission from the authorities and local communities. It is favoured by the planned legal regulations that serve to start business in areas dominated by the existing monopolists.

The aim of the paper is to show new trends in the field of protection against threats and the evolution of water-supply systems.

\section{Smart water supply network}

Smart Grids in the Collective Water Supply Systems (CWSS) intelligently integrates activities of all the participants of the processes of production, transmission, distribution and usage, in order to provide water in an economical, certain and safe way [12].

In the Smart Grids the flow of water and information occurs in real time, as shown in the Fig. 1.

The following programs are used for simulation (types of algorithms):

- simulation - for the predicted situations, 
- monitoring threats,

- adaptive - network structure is adjusted to the existing situation,

- repairing - choosing a variant of repair.

In general, prediction of situations and making decisions in order to maximize benefits and minimize losses. A pillar of the smart grid is smart metering. Programmable water meters and their remote reading, flow measurement, failure detection (remote), central and dispersed analytics, communication with a customer.

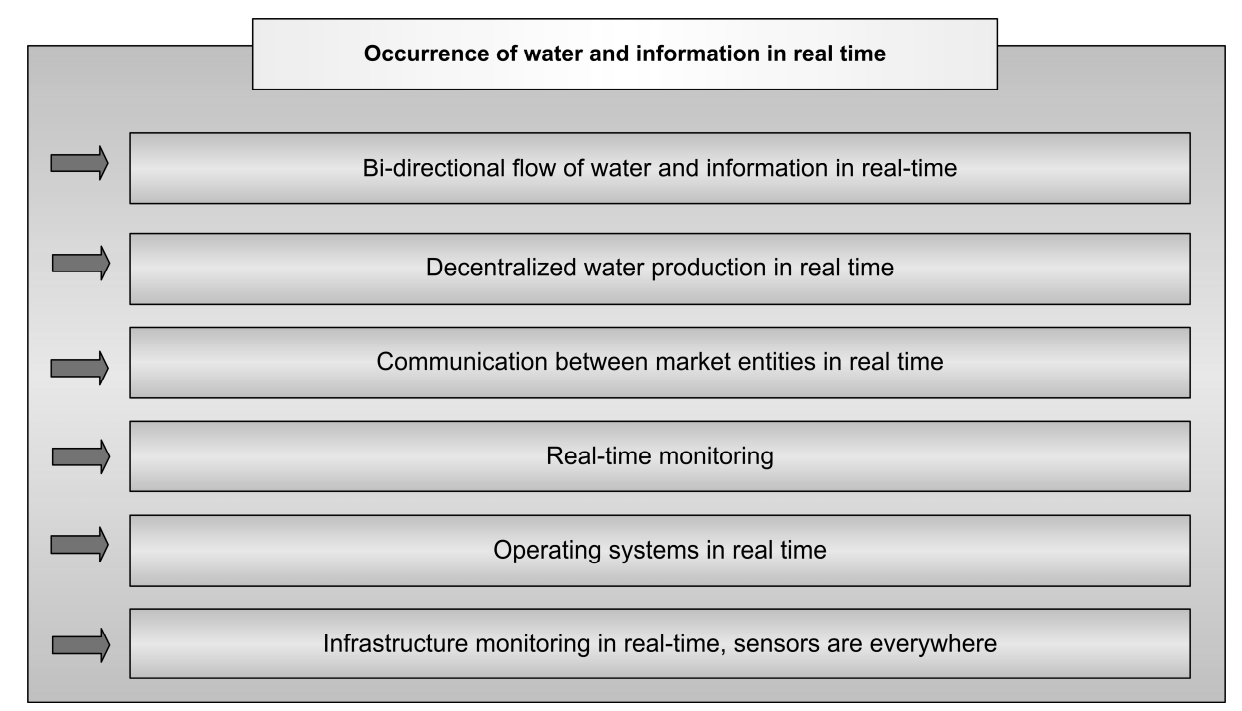

Fig. 1. The exemplary of water and information flow in the Smart Grids

Rys. 1. Przykład przepływu informacji w inteligentnych sieciach

In the perspective of the needs of dispersed sources of water supply, smart water meter box will become necessity, their owners will be the water recipients and the meters will be able to register consumption and to manage demand in crisis situations.

If there is a threat of water deficit or during failure the restrictions in drinking water supply to consumers can occur. In the first place the methods of water rationing are used consisting in the voluntary participation of consumers as a demand side. For a certain gratification the customer expresses his/her willingness to reduce water consumption at the CWSS operator request and even agrees to suspend water supply. If such possibilities run out, the following solutions can be used:

- rotational areas or recipients shut off. This kind of proceeding leads to a temporary restriction of water supply to many recipients and does not allow for long lack of water supply for only some of them, 
- at the recipients with "smart water meters" the acceptable water consumption limits can be set,

- introduction of a tariff "consent for incidental water shut off with a reasonable discount", that means such customers who would agree to be temporary without water paying little less for water.

Outsourcing means that an organization entrusts the implementation of specific process to outside service providers, specifying in details the effects that the customer intends to obtain. It applies to non-core business which requires experience and expertise in side fields.

\section{New approach to protection of water supply objects}

In 1996 in Calgary, Canada, the first international conference on CPTED (Crime Prevention through Environmental Design) was organized and the International Association of CPTED was established. The CPTED strategy shaping is one of the tools, whose introduction in conjunction with other solutions leads to significant reduction in number of adverse events and to faster response of the authorities responsible for safety.

In highly developed countries of Western Europe and the United States the second generation CPTED strategy is implemented, which presents a new look at the elements of critical infrastructure by protecting them against possible crimes, terrorism, sabotage and disasters $[4,11]$. In Poland, the problem of effective protection of critical infrastructure is highlighted by the Law on Crisis Management. The relevant records say that protection of critical infrastructure should predict appropriate protection of critical components from attacks, failures and other undesirable events.

Critical infrastructure protection also includes actions aimed at ensuring the continuity of operation, functionality, integrity, in order to prevent the risk of threat $[13,15]$. Attention is also drawn to the reduction and neutralization of the effects and quick reconstruction of the infrastructure in order to limit the consequences for human security [1].

Regardless of the ongoing discussions, whether the city is a human invention or a natural consequence of socio-cultural development, there is no doubt that it is a space created by man for man. The democratization of social life is the release of all the possibilities of creative energy lying in the community [2,3].

Proper planning and efficient use of the built environment can lead to a reduction in fear of crime and the frequency of its occurrence, as well as to improving the quality of life [14]. The purpose of the CPTED is to reduce criminal opportunity, which can be integrally associated with the projects of objects or their environment.

Territoriality:

- symbolic barriers - signs, marks,

- real barriers - fences, landscaping, 
We can distinguish the following types of area:

- public - available for everyone,

- semipublic - under control,

- semi private - shared by authorized groups,

- private - personal for individuals.

Natural surveillance.

The feeling of being watched, the sense of anonymity is reduced - see-through fencing, lighting.

Types of surveillance:

- natural - area designing,

- formal - guards,

- mechanical - CCTV,

Access control:

- a clear designation between the different types of areas, elimination of unnecessary roads of retreat, channeling of traffic.

Target hardening.

Visible security systems hardening:

- burglar doors, adequate locks, burglar alarms.

Management and maintenance/appearance:

- plan of area management, proper landscaping and its maintenance, fast repairs a positive image of the area suggests that the relevant services operate properly.

Activity support:

- signs and markings indicating how to use the area, the location of roads, pedestrian and car traffic.

In Poland, the act on spatial planning and spatial development is applied. Spatial planning should take into account the requirements of health protection and safety of people and property, as well as the needs of disabled people. In turn, spatial development must take into account the issues of prevention from external threats and internal threats, especially threats to safety and public order.

The main sense of the CPTED idea is based on the assumption that the elimination of reinforcing stimuli causes that the offence will not be committed. Active design takes into account existing risk of crime due to factors related to the potential perpetrator and situational factors.

Positive design means that at the design stage crime problem is not taken into account and there is a need to introduce additional safety standards (offence = threat), e.g.: doors are tested for being broken and unlocked at a specific time. External doors are locked automatically and outer handle is replaced with a fixed knob.

The terminology "crime prevention through environmental design" was introduced by C. Ray Jeffery and significantly expanded in the book of the same title, published in 1971. 
In turn, the theoretical work of architect Oscar Newman draw attention to the link between crime and the environment (surroundings) in which it will be committed. He indicated correlation between the form of buildings and the level of crime.

Stimulating citizenship activity still remains the biggest obstacle to the implementation of the CPTED. In the early 2000s, during the escalation of the Israeli-Palestinian conflict, irresponsible prank of Iberian student of local University in Rzeszow took place. In the afternoon, the student walked in the area of network clean water tanks in the district Pobitno and shouting incomprehensible sentences in Arabic scattered white powder on the tank domes. The residents of the surrounding blocks noticed it and informed the police about the incident. As a result of the investigation it turned out that the white powder was flour and unbalanced student of Arabic origin has undergone specialized psychiatric examination. Although the potential threat proved to be a provocation, alertness of the residents deserve credit.

The gate should be installed in a place easy to be observed, including residents of the neighbouring buildings. Its design must prevent climbing over it, must have a good visibility on both sides, must be resistant to vandalism and easy to maintain, illuminated at night.

Dobczyce Reservoir - coastline fenced and planted with thorny plants, noboating, territorial signs, the so-called markers.

\section{The issue of water supply systems decentralization}

Almost every day some information appears about the events that cause turbulence showing characteristics of crisis. Their number and variety make it difficult to be prepared for each of them. Water companies direct their activities to the most likely events that have a negative impact on achieving the objective. It leads to the need of risk evaluation and risk evaluation, unfortunately, is also associated with real risk.

In Poland, for population 38.5 million, there are 40 thousand human settlements with 39 thousand that have less than $2000 \mathrm{~m}^{2}$ and are inhabited by about $38.5 \%$ of the population, i.e. 14.7 million people. $86 \%$ of the population is covered by the central water supply system. The dispersed system is the system producing up to $1000 \mathrm{~m}^{3}$ of water per day (servicing 5000 inhabitants) [10].

The residents of the Silesian province during the day consume about $875000 \mathrm{~m}^{3}$ of water intended for human consumption from a collective supply and about $55000 \mathrm{~m}^{3}$ of water from the wells, public sources, etc. In the midnineteenth century, in defence against an outbreak of epidemic, some decisions about the construction of collective water supply system were made. These concepts did not include the supply of individual cities but the region as a whole.

Currently, the Upper Silesian Waterworks (USW) produces $80 \%$ and the remaining waterworks $20 \%$ of water. In the years 1949-1950, 3 companies were 
combined creating the Provincial Water and Sewerage Company. In 1991, 16 local waterworks and the USW located in Katowice remained.

A trend of declining water sales has been observed. Building own water intakes by wholesale buyers, the USW becomes a spare source. Buying water in competitive enterprises and even import from the Czech Republic.

Recently, in the USW 8 Water Treatment Plants (WTP) were liquidated, which is associated with an excluding from the operation certain sections of the water supply network. This, in turn, leads to a loss of emergency water transfers. Production capacity of the USW is $900000 \mathrm{~m}^{3} / \mathrm{d}$ and currently it produces $450000 \mathrm{~m}^{3} / \mathrm{d}$, while $\mathrm{Q}_{\mathrm{dmax}}$ is $600000 \mathrm{~m}^{3} / \mathrm{d}$.

The action strategies of waterworks should already initiate actions on the change and extension of activity profile beyond today's income from water sales. The formation of Autonomous Areas of Water Supply (AAWS) will require common water supply policy of local government units (municipalities, counties, districts, metropolises), operating in one area. The operator supervision over the AAWS can be provided as a comprehensive service by the existing structure of centralized water companies, featuring a potential of professional management.

It should be expected that the AAWS will be business ventures having legal personality to conduct business. It seems that substitutes of such activities are occurring Regional Water Clusters.

Examples of tasks:

- preparing water supply strategy of AAWS in the form of coherent plans,

- methods for optimizing water production and distribution in the area of AAWS operation,

- preparation and introduction of modern technologies and techniques using local water resources,

- conducting investments in the AAWS area,

- exploitation of existing technical infrastructure,

- participation in legislative works, setting budgets and policies for obtaining financial resources for the AAWS development.

\section{Conclusions}

- In highly developed countries, the trend of the developing small and dispersed water supply is observed. It occurs in rich countries with high technical culture, since only such conditions allow for meeting the standards of water supply reliability and water health safety.

- Protection systems must be certain and efficient, which represent the potential of safety water supply. Progress in the systems functioning, analysis of undesirable events and the use of smart grid makes progress in system protection, which in water supply should take into account the requirements of national regulations, trends and international standards, as well as threats inside water supply systems and their environment. Water supply systems should be sub- 
jected to a specialized monitoring procedure for all the potential threats carrying negative consequences.

- Awareness of difficult times related to water deficits will cause that society would react by an increased interest in scattered local water sources. It seems that the strategists have already prepared probable scenarios in that regard. None of them implies that it will be as it was because it is simply impossible.

- The transition from centralized to scattered systems will not happen within a few years. It may even take several decades, depending on the implementation of the scenarios associated with global water deficit in a national, regional or world scale. The second generation CPTED emphasizes the environmental objectives and the design of the so-called "defensible space". The mission of building positive relationships between economic and social development and environmental protection is in the interest of present and future generations.

\section{Literature}

[1] Britton T.C., Stewart R.A., O'Halloran K.R.: Smart metering: enabler for rapid and effective post meter leakage identification and water loss management, Journal of Cleaner Production, Volume 54/2013, pp. 166-176.

[2] Di Nardo A., Di Natale M., Greco R., Santonastaso G.F.: Ant algorithm for smart water network partitioning, Procedia Engineering, Volume 70/2014, pp. 525-534.

[3] Gurung T.R., Stewart R.A., Sharma A.K., Beal C.D.: Smart meters for enhanced water supply network modeling and infrastructure planning, Resources Conservation and Recycling, Volume 90/2014, pp. 34-50.

[4] Oscar N.: Defensible space, crime protection through urban design, Macmillam 1972.

[5] Pietrucha-Urbanik K.: Assessment model application of water supply system management in crisis situations, Global NEST Journal, 16(5) 2014, 893-900.

[6] Pietrucha-Urbanik K.: Prioritizing water pipe renewal using fuzzy set theory, Journal of KONBiN 1(33)2015, s. 243-250. DOI 10.1515/jok-2015-032.

[7] Rak J.: Bezpieczna woda wodociągowa. Zarządzanie ryzykiem w systemie zaopatrzenia w wodę. Oficyna Wydawnicza Politechniki Rzeszowskiej, Rzeszów 2009.

[8] Rak J.: Istota ryzyka w funkcjonowaniu systemu zaopatrzenia w wodę. Oficyna Wydawnicza Politechniki Rzeszowskiej, Rzeszów 2004.

[9] Rak J.R.: Propozycja oceny dywersyfikacji objętości wody w sieciowych zbiornikach wodociągowych, Czasopismo Inżynierii Lądowej, Środowiska i Architektury, JCEEA, t. XXXII, z. 62 (1/15), 2015, s. 339-349. DOI: 10.7862/rb.2015.23.

[10] Ramm-Szatkiewicz K.: Plany Bezpieczeństwa Wody coraz popularniejsze w Europie. Wodociągi-Kanalizacja, $\mathrm{Nr} 1(131) / 2015$, s. 22-23.

[11] Randall I.: 21st century Security and CPTED: Designing for Critical Infrastructure Protection and Crime Prevention, Atlas, 2008.

[12] Sobczak A., Kulisiewicz T.: Smart city. Jak zbudować inteligentne miasto? Przegląd Komunalny, nr 2/2015, s. 40-41. 
[13] Ustawa z dnia 26 kwietnia 2007 r. o zarządzaniu kryzysowym (Dz. U. 2007, Nr 89, poz. 590 , z późn. zm).

[14] Ustawa z dnia 27 marca 2003 r. o planowaniu i zagospodarowaniu przestrzennym (Dz.U. 2003, Nr 80, poz. 717, z późn. zm).

[15] WHO: Guidelines for Drinking Water Quality, World Health Organization, Geneva 2004.

\section{NOWE KIERUNKI OCHRONY I EWOLUCJI SYSTEMÓW WODOCIĄGOWYCH - INTELIGENTNE ZAOPATRZENIE W WODE}

\section{Streszczenie}

System wodociągowy powinien charakteryzować się doskonałą ochroną na wypadek wystąpienia niepożądanych zdarzeń. W przyszłości ochrona tych systemów będzie zapewniona poprzez ich inteligentne zarządzanie $\mathrm{z}$ wykorzystaniem rozwiązań typu smart metering oraz wdrażanie strategii CPTED drugiej generacji przedstawiającej nową perspektywę ochrony elementów infrastruktury krytycznej, uwzględniającej ewentualne przestępstwa, terroryzm, sabotaż, czy też katastrofy. W pracy przedstawiono problematykę skutecznej ochrony infrastruktury krytycznej oraz zwrócono uwagę na właściwe zabezpieczanie elementów krytycznych przed atakami, awariami i innymi zdarzeniami niepożądanymi. Na tym tle sformułowano zasady ochrony systemów wodociągowych, którego celem jest przygotowanie zasobów i społeczeństwa na wypadek wystąpienia zdarzeń niepożądanych powodujących zagrożenie zarówno dla zdrowia człowieka, jak i dla infrastruktury. W przypadkach możliwości zarządzania włączeniami konkretnych odbiorców, a nie tylko obszarów, powinno ustalić się priorytet ważności zapewnienia dostawy wody. Wyłączenie gospodarstw domowych wydaje się być rozwiązaniem przynoszacym najmniejsze straty finansowe. Należałoby jednak zwrócić uwagę na wyłączenia tzw. klientów wrażliwych, np. ludzi niepełnosprawnych, osób w podeszłym wieku, rodzin z małymi dziećmi itp. Za właściwą obsługę infrastruktury komunalnej odpowiadają wyspecjalizowane przedsiębiorstwa, które oprócz zarządzania wymienionymi systemami są jednocześnie odpowiedzialne za zapewnienie ochrony wrażliwych elementów będących w ich powiązaniu lub użytkowaniu. Najbardziej oczywistym przykładem systemów miejskiej infrastruktury krytycznej jest system zbiorowego zaopatrzenia w wodę.

Słowa kluczowe: ochrona, smart grid, decentralizacja systemów wodociągowych, zaopatrzenie w wodę

Przestano do redakcji: $30.05 .2015 r$.

Przyjęto do druku: $30.10 .2015 \mathrm{r}$.

DOI: $10.7862 / \mathrm{rb} .2015 .121$ 